\title{
Estrogen modulating effects of resveratrol in female rats
}

\author{
Resveratrolün dişi sıçanlarda oluşturduğu estrojen modülatörü etkileri
}

Fikriye Yasemin ÖZATIK, Kevser EROL, Orhan ÖZATIK

\begin{abstract}
Objectives: This study investigates the estrogen-like effects of resveratrol (RES) in female rats.

Materials and Methods: In this two-step study on estrogenlike activity of RES, immature female rats (21 days old) were used in the first step and pubertal female rats (28 days old) with primary ovarian failure (POF) induced by 4-vinylcyclohexene diepoxide (VCD) were used in the second step. Possible agonistic and/or antagonistic effects of RES were investigated by using several parameters including the ratios of uterine/body weights (UBW), uterine dry/wet weights (UDWW) and body weight increase (BW\%), bone density measurement, serum estradiol and vitamin D levels and histological evaluation.
\end{abstract}

Results: In immature rats, RES resulted in an increase in UBW equal to that produced by 17 alpha-ethinyl estradiol (17alphaEE). The minimum effective dose for RES was $10 \mathrm{mg} / \mathrm{kg}$. This effect was not decreased by tamoxifen but was significantly antagonized by fulvestrant. Similarly, tamoxifen did not abolish the effects of RES completely in rats with POF. However, in rats with VCDinduced POF, tamoxifen resulted in lower UBW values and estradiol levels were significantly higher in 17alphaEE-treated, RES+tamoxifen-treated and 17 beta-estradiol (17betaE)-treated rats compared to control animals.

Conclusion: The dose of RES may be important in terms of estrogenic activity and even RES may modulate the effects of estrogen.

Keywords: Estrogen, Resveratrol, 4-vinylcyclohexene diepoxide, Primary ovarian failure

\author{
Fikriye Yasemin Özatik (四) \\ Department of Pharmacology, Faculty of Medicine, Ahi Evran University, \\ Kirsehir, Turkey \\ e-mail:fyozatik@hotmail.com \\ Kevser Erol \\ Department of Pharmacology, Faculty of Medicine, Osmangazi University, \\ Eskişehir, Turkey \\ Orhan Özatik \\ Department of Histology and Embriology, Faculty of Medicine, Ahi Evran \\ University, Kursehir, Turkey
}

Submitted/Gönderme: 02.02 .2016

Accepted/Kabul: 29.03.2016

\section{öz}

Amaç: Çalışmamızda resveratrol (RES)'ün dişi sıçanlarda oluşturduğu estrojenik etkilerin incelenmesi amaçlanmıştır.

Gereç ve Yöntem: Çalışmamızın ilk aşamasında, RES'ün, immatür (21 günlük) dişi sıçanlarda, 2. aşamasında 4-vinilsiklohekzen diepoksid (VCD) enjeksiyonu ile primer over yetmezliği (POY) oluşturulan puberte dönemindeki (28 günlük) dişi siçanlarda oluşturduğu estrojenik etkileri incelenmiştir. RES'ün agonist ve/veya antagonist etkileri çeşitli parametreler kullanılarak araştırılmıştır. $\mathrm{Bu}$ parametreler uterus ağırlı̆̆ $1 /$ vücut ağırlığ oranları(UA/VA), uterus kuru ağırlığı/uterus yaş ağırlı̆g1 oranları (UKA/UYA), VA artış oranları, kemik dansitometresi, serum estradiol ve vitamin D değerleri ve histolojik değerlendirmedir.

Bulgular: İmmatür sıçanlarda UA/VA oranları değerlendirmesinde RES, UA/VA oranını 17 alfa-etinil estradiol (17alfaEE)'e benzer bir şekilde arttırmıştır. En düşük anlamlı etki $10 \mathrm{mg} / \mathrm{kg}$ RES dozunda görülmüştür. Bu etki tamoksifen ile azalmazken fulvestrant ile anlamlı bir şekilde antagonize edilmiştir. POY oluşturulmuş dişi sıçanlarda da tamoksifen, RES'ün etkilerini tamamen ortadan kaldırmamıştır. UA/VA değerleri açısından POY geliştirilmiş sıçanlarda VCD+RES10mg/kg+tamoksifen verilen grubun ortalama değerlerinin, $\mathrm{VCD}+\mathrm{RES} 10 \mathrm{mg} / \mathrm{kg}$ verilen grubun ortalama değerlerinden daha düşüktür. POY geliştirilmiş siçanlarda estradiol değerleri incelendiğinde, VCD+17alfaEE, siçanlarda $\mathrm{VCD}+\mathrm{RES} 10 \mathrm{mg} / \mathrm{kg}+$ tamoksifen ve $\mathrm{VCD}+17$ betaestradiol (17betaE) verilen gruplarda estradiol değerlerinin kontrol değerlerine göre anlamlı derecede arttığı gözlenmektedir.

Sonuç: Çalışmamızın sonucuna göre estrojenik aktivite açısından RES'ün dozu önemli bir faktör olabilir ve RES'ün estrojen modülatörü olarak etki ettiği söylenebilir.

Anahtar kelimeler: Estrojen, Resveratrol, 4-vinilsikloheksen diepoksid, Primer over yetmezliği

\section{Introduction}

Resveratrol (trans-3,5,4'-trihydroxystilbene) (RES) is a natural polyphenol that is synthesized as a phytoalexin by the herbals. It is found abundantly in several foods including grapes, berries, nuts and red wine. It is well known that RES has many pharmacological effects such as antioxidant, antiinflammatory, analgesic, cardioprotective, 
neuroprotective, antiaging [1,2] and antitumoral activities [3]. RES is also known as a phytoestrogen. RES was reported to bind to estrogen receptors and compete with 17 betaestradiol (17betaE) in vitro [2,4]. Because of the structural similarity of RES and diethylstilbestrol, a synthetic estrogen, it was postulated that RES may have an estrogenic activity. However, it is controversial that whether resveratrol is an estrogen agonist or antagonist. While several authors suggested that RES has an estrogenic activity [4,5], others noted an antiestrogenic activity $[6,7]$.

In the present study, we investigated the putative estrogenic effects of RES on uterine growth in a female immature (21 days old) rat model, which is a widely accepted model for the studies of in vivo estrogen agonistic and/or antagonistic effects $[5,8]$. In the second step, the estrogenic activity was investigated in pubertal female rats (28 days old) with primary ovarian failure (POF) induced by 4 -vinylcyclohexene diepoxide (VCD) $[9,10]$. Uterine growth and differentiation, ovarian differentiation, body weight, bone densitometry and serum levels of estradiol and vitamin $\mathrm{D}$ were evaluated. In vivo effects of RES were compared with those of 17 alpha-ethynyl estradiol (17alphaEE) and 17betaE.

\section{Materials and Methods}

Sprague-Dawley female rats, used in all studies, were supplied by the Medical and Surgical Experimental Research Center of Eskisehir Osmangazi University. All animals had free access to water and a pelleted commercial diet. The experiments were conducted in accordance with the protocol approved by the Animal Care and Use Committee of Eskisehir Osmangazi University.

\section{Immature female rat study}

Twenty-one days-old Sprague-Dawley female rats weighing approximately $35-40 \mathrm{~g}$ were treated by oral gavage with either vehicle (\%20 Dimethyl sulfoxide (DMSO) (SigmaAldrich, St. Louis, MO,USA)/water), RES (Sigma- Aldrich, St. Louis, MO, USA) at doses of 2,10 or $20 \mathrm{mg} / \mathrm{kg} /$ day (RES2, RES10, RES20), or 17alphaEE (Sigma- Aldrich, St. Louis, MO,USA) at a dose of $30 \mu \mathrm{g} / \mathrm{kg} /$ day [11] for 3 days. Tamoxifen (TMX) (Sigma- Aldrich, St. Louis, MO, USA) $(2 \mu \mathrm{g} / \mathrm{kg} /$ day) and fulvestrant (FLV) (Sigma- Aldrich, St. Louis, MO,USA) $(5 \mathrm{mg} / \mathrm{kg} /$ day) were used as estrogenic antagonists. Animals were divided into 10 groups with six animals in each: Control, 17alfa-EE, RES2, RES10, RES20, RES2+17alfaEE, RES10+TMX, RES10+FLV,
17alfaEE+TMX, 17alfaEE+FLV. Because it was predetermined to use the minimum effective dose for RES in groups treated with FLV and TMX, $10 \mathrm{mg} / \mathrm{kg}$ RES was coadministered with FLV- and TMX-treated groups.

The overnight-fasted rats were weighed 24 hours after the final dose and $1 \mathrm{ml}$ of blood was withdrawn by cardiac puncture under the ether anesthesia and collected into dry tubes. Serum samples obtained by centrifugation were stored at $-40^{\circ} \mathrm{C}$ until analysis. The animals were sacrificed by an overdose of anesthesia and autopsied. After the measurement of uterine wet weight, the uterus was cut into two pieces. One of them weighed again, placed on stainless steel drying shelf in an oven at $60{ }^{\circ} \mathrm{C}$ for 12 hours and the uterine dry weight was measured. The other part of the uterus was used for histological analysis.

\section{Peripubertal female rat with primary ovarian failure study}

28 days-old Sprague-Dawley female rats weighing 40-50 $\mathrm{g}$ were used in this step. A total of 6 groups containing 6 animals in each were used: Control, VCD, VCD+17alfaEE, VCD+RES10, VCD+RES10+TMX, VCD+17betaE. Only the minimum effective RES dose $(10 \mathrm{mg} / \mathrm{kg} / \mathrm{day})$ predetermined in immature female rat study was used in this step of the study. VCD (Fluka, Buchs, Switzerland) was dissolved in DMSO and injected to the animals at a dose of $60 \mathrm{mg} / \mathrm{kg} /$ day for 15 days [9,12]. Twenty-four hours after the last injection, RES at a dose of $10 \mathrm{mg} / \mathrm{kg} /$ day (the dose that exerted least estrogenic activity in immature female rat study) 17 alpha-EE at a dose of $30 \mu \mathrm{g} / \mathrm{kg} / \mathrm{day}$ [11] or 17betaE (Sigma- Aldrich, St. Louis, MO,USA) at a dose of $0.4 \mathrm{mg} / \mathrm{kg} / \mathrm{day}$ [13] was given to the animals by oral gavage for 3 days. TMX ( $2 \mu \mathrm{g} / \mathrm{kg} /$ day) and FLV ( $5 \mathrm{mg} / \mathrm{kg} /$ day) were also used as estrogenic antagonists. DMSO was given to the control animals. Sample collection and other procedures were same as the first step.

\section{Morphometrical evaluations}

The ratios of uterine wet weight to body weight (UW/BW; $\mathrm{mg} / \mathrm{g}$ ) and uterine dry weight to uterine wet weight (UDW/ UWW; g/g), and the percentage of body weight increase [(BW on the last day - BW on the first day of the experiment) $\mathrm{x} 100 / \mathrm{BW}$ on the first day] were calculated.

\section{Uterine and ovarian histology}

Formaline-fixed uteri and ovaries were used for conventional 
paraffin embedding process. Sections of about $3-\mu \mathrm{m}$ thickness were cut from each block. Slides were stained with hemotoxylin and eosin before undergoing image analysis for measurement of the endometrial epithelium and myometrial thicknesses. Samples were evaluated by using a light microscope (Olympus U-PM-TVC) and pictures were taken with Olympus Q color 3 digital camera.

The thickness of endometrial epithelium was measured. Increase in the endometrial epithelium thickness, hypertrophy in the uterus, increase in mitotic cell numbers, spindle-shaped cells underlying basal lamina and cells with a dark nuclei were considered as signs of increased estrogenic activity. On the other hand, decreased endometrial epithelium thickness, cubical shape in epithelial cells, round-shaped cells underlying basal lamina, cells with round nuclei and atrophic appearance of the uterus were considered as the antagonistic characteristics of substances (Fig. 1).

a
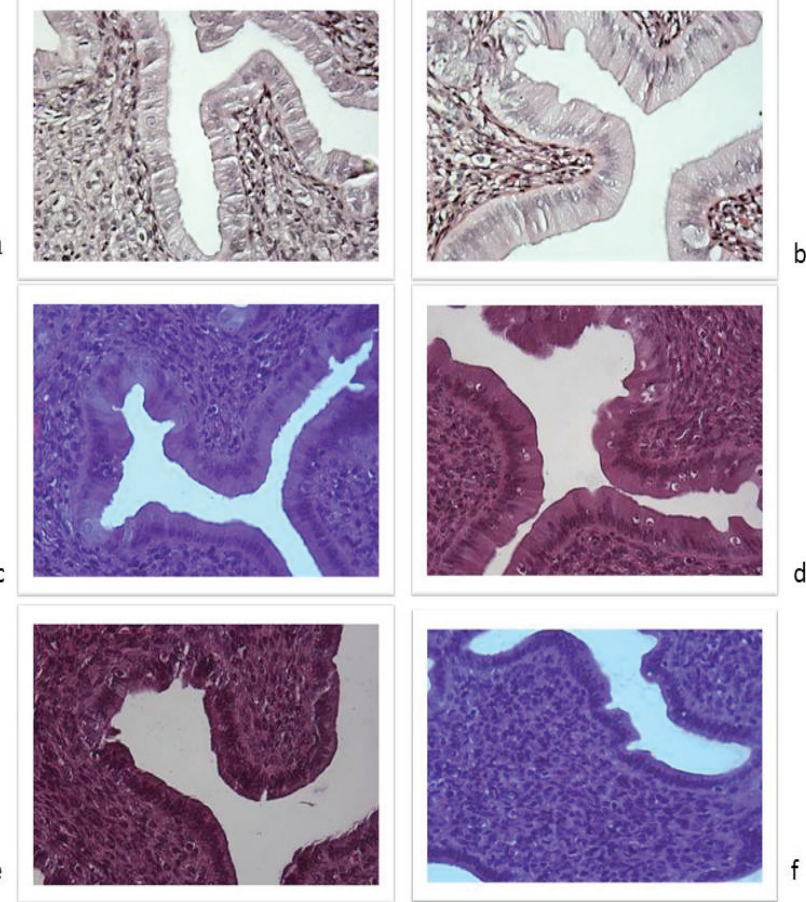

Fig. 1. The histological images of the uteri of immature female rats (a)Control, (b)17 alpha EE, (c)RES 2+17 alpha EE, (d)17 alpha EE +TMX, (e)RES $10+$ TMX, (f)RES $10+$ FLV X 400

Follicles in the ovary were examined. Decreased or increased number of primary and primordial follicles compared to the control group was considered as ovarian failure or estrogenic activity, respectively (Fig. 2). All histological analysis was performed by a histologist blinded to the groups.
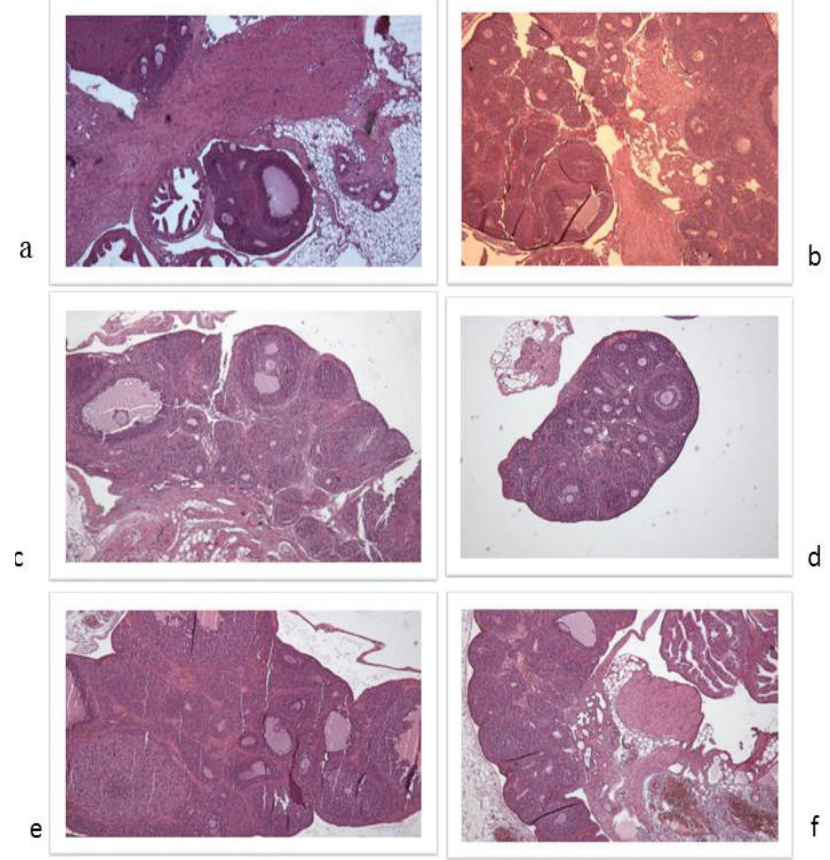

Fig. 2. The histological images of the ovaries of peripubertal female rats with $\mathrm{POF}$ (a)Control, (b) VCD, (c)VCD +17 alpha EE, (d)VCD+RES 10, (e) VCD+RES10+TMX, (f)VCD+17 beta E X 400

\section{Bone mineral density measurements}

The right femur of rats with POF was removed during autopsy and scanned ex vivo using DEXA scanner (Norland XR-46, Norland Corp, Fort Atkinson,VI) equipped with a software to be used in measurements on small-sized animals. Resolution of scanning was $0.5 \times 0.5 \mathrm{~cm}$ and rate of scanning was $60 \mathrm{~mm} / \mathrm{sec}$.

\section{Serum estradiol and vitamin D analysis}

The serum concentration of estradiol was determined by enzyme immunoassay, using a commertially available kit (Estradiol EIA Kit. Cayman Chemical Company,Ann Arbor,USA) Serum 25-hydroxy vitamin D levels were determined in rats with POF with a commercially available ELISA kit (Immunodiagnostic Systems Limited, Boldon, UK).

\section{Statistical analysis}

The data were expressed as mean \pm SD. Significance was determined by one way ANOVA test and multiple comparison test of TUKEY. $\mathrm{P}$ values of $<0.05$ were considered to be statistically significant. 


\section{Results}

There were no significant differences in body weight gains of the immature animals. RES increased the UW/BW in a dose-dependent manner, with no significant difference between the doses of $10 \mathrm{mg} / \mathrm{kg}$ and $20 \mathrm{mg} / \mathrm{kg}$. The activity observed with $10 \mathrm{mg} / \mathrm{kg}$ resveratrol was equal to that produced by 17 alphaEE. The increases in UW/BW were inhibited insignificantly with the addition of TMX but significantly with the addition of FLV $(\mathrm{p}<0.001)$ (Fig. 3). The ratio of uterine dry weight/wet weight in all groups was not different from the control group except the combination with FLV. Combination of 17alphaEE and FLV significantly increased the UDW/UWW (Fig. 4).

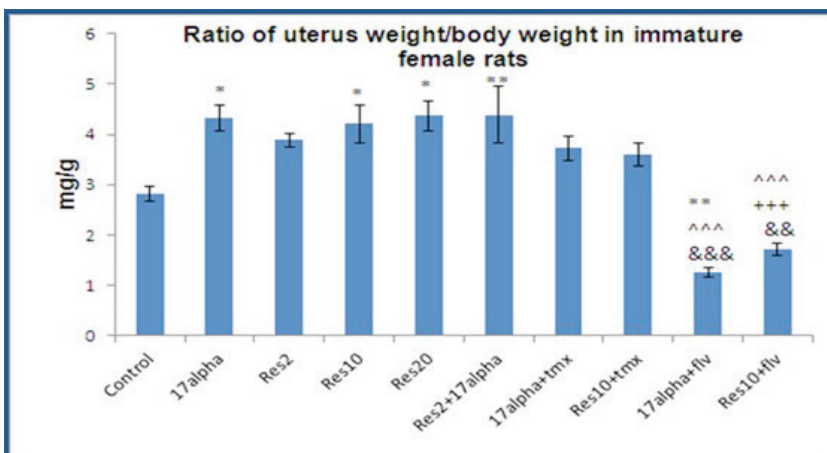

Fig. 3. Ratio of uterus weight/body weight in immature female rats $(\mathrm{n}=6)$

$(*)=$ Different from control, $(*)=\mathrm{p}<0.05,(* *)=\mathrm{p}<0.01$

$(+)=$ Different from Resveratrol $(10 \mathrm{mg} / \mathrm{kg})(\operatorname{RES} 10),(+++)=\mathrm{p}<0.001$

$(\wedge)=$ Different from 17alpha ethynyl estradiol (17alpha EE), $\left({ }^{\wedge \wedge}\right)=\mathrm{p}<0.001$ $(\&)=$ Different $\quad$ from $\quad$ Res10+tamoxifen $\quad(T M X), \quad(\& \&)=\mathrm{p}<0.01$, $(\& \& \&)=\mathrm{p}<0.001$

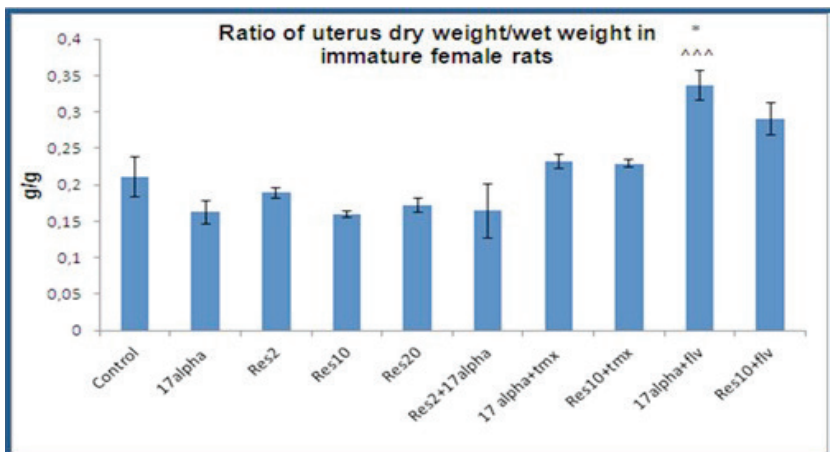

Fig. 4. Ratio of uterus dry weight /wet weight in immature female rats $(\mathrm{n}=6)$

$(*)=$ Different from control, $(*)=\mathrm{p}<0.05$

$(\wedge)=$ Different from 17alphaEE, $\left({ }^{\wedge \wedge \wedge}\right)=\mathrm{p}<0.001$

Endometrial thickness was significantly increased in 17alphaEE and 17alphaEE + TMX groups $(\mathrm{p}<0.001)$ and also in RES10 $(\mathrm{p}<0.01)$ and RES20 $(\mathrm{p}<0.001)$ groups compared to the control group. RES increased the endometrial thickness in a dose-dependent manner. However, these effects of RES at all three doses were significantly lower than that of 17 alphaEE $(\mathrm{p}<0.001)$. Endometrial thickness was significantly decreased in 17alphaEE+FLV and RES10+FLV groups $(p<0.001)$ compared to the control group, indicating the antagonistic effect of FLV.

Endometrial thickness was also significantly increased in RES2+17alphaEE group compared to the control and 17 alphaEE groups $(p<0.001)$, but was quite similar between RES10+TMX and control groups.

17alphaEE $(p<0.001)$ and RES at the doses of $10 \mathrm{mg} /$ $\mathrm{kg}(\mathrm{p}<0.01)$ or $20 \mathrm{mg} / \mathrm{kg}(\mathrm{p}<0.001)$ significantly increased endometrial thickness in immature rats $(\mathrm{p}<0.001)$. FLV but not TMX inhibited these effects of 17 alphaEE and RES10 $(\mathrm{p}<0.001)$ (Fig. 5). Interestingly, RES2 inhibited the effects of 17 alphaEE $(\mathrm{p}<0.001)$ on the endometrial thickness (Figs. $1,5)$. Serum estradiol levels was inhibited significantly by RES20 ( $\mathrm{p}<0.05)$ as compared to $10 \mathrm{mg} / \mathrm{kg}$ in immature rats group (Fig. 6).

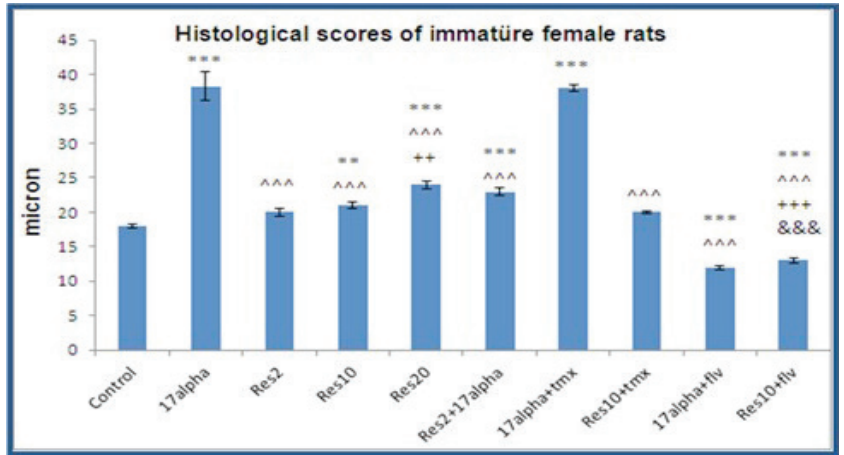

Fig. 5. Histological scores of immature female rats (Based on endometrial thickness $)(n=6)$

$(*)=$ Different from control, $(* *)=\mathrm{p}<0.01,(* * *)=\mathrm{p}<0.001$

$\left({ }^{\wedge}\right)=$ Different from 17 alpha EE, $(\wedge \wedge \wedge)=p<0.001$

$(+)=$ Different from $\operatorname{Res} 10,(++)=\mathrm{p}<0.01,(+++)=\mathrm{p}<0.001$

$(\&)=$ Different from Res10+TMX, $(\& \& \&)=\mathrm{p}<0.001$

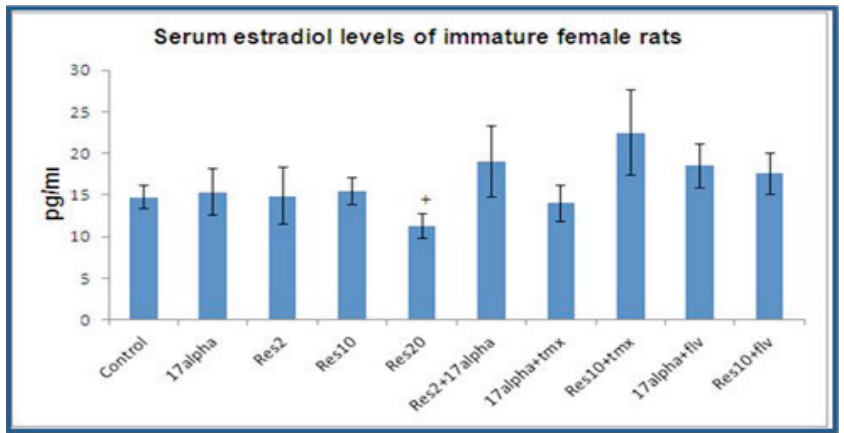

Fig. 6. Serum estradiol levels in immature female rats $(n=6)$. $(+)=$ Different from RES10, $(+)=\mathrm{p}<0.05$ 


\section{Primary ovarian failure groups}

VCD significantly decreased UW/BW ( $<<0.01)$. 17alphaEE did not reversed this effect but RES10 $(p<0.05)$ and 17 betaE $(p<0.01)$ significantly reversed the effects of VCD. (Fig. 7). But no significant differences were observed in UDW/UWW in none of the VCD-treated groups. RES10 and 17betaE significantly increased the percentage of body weight and TMX did not reverse these effects of RES (Fig. 8).

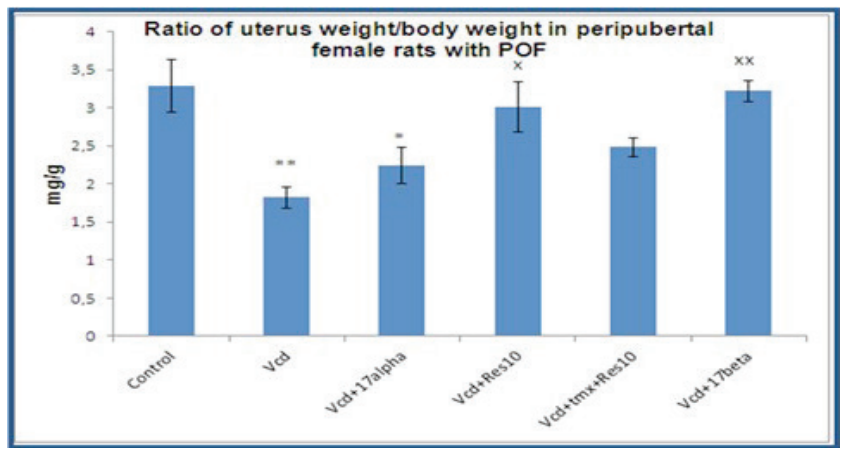

Fig. 7. Ratio of uterus weight/body weight in peripubertal female rats with POF $(n=6)$

$\left(^{*}\right)=$ Different from control, $(*)=\mathrm{p}<0.05,(* *)=\mathrm{p}<0.01$

$(\mathrm{x})=$ Different from $\mathrm{VCD},(\mathrm{x})=\mathrm{p}<0.05,(\mathrm{xx})=\mathrm{p}<0.01$

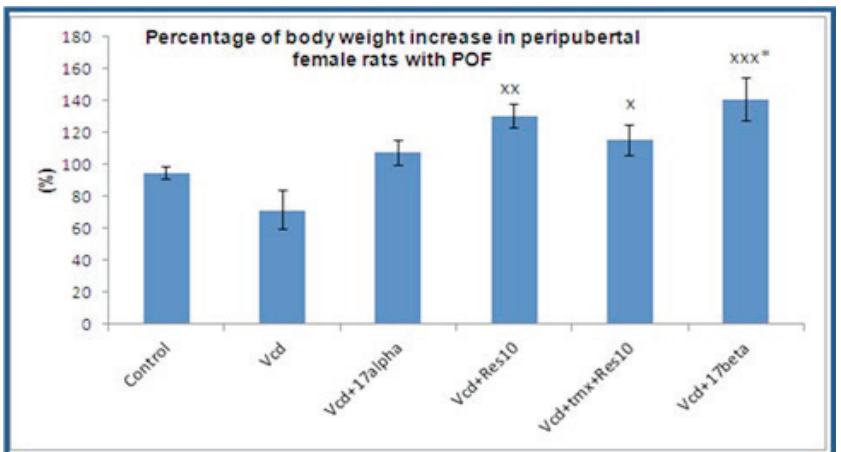

Fig. 8. Percentage of body weight increase in peripubertal female rats with POF $(n=6)$

$(*)=$ Different from control, $(*)=\mathrm{p}<0.05$

$(x)=$ Different from VCD, $(x)=p<0.05,(x x)=p<0.01,(x x x)=p<0.001$

A significant decrease was observed in endometrial thickness of VCD-treated groups compared to the control group $(p<0.001)$. 17alphaEE, RES10 and 17betaE significantly reversed the effects of VCD $(p<0.001)$. TMX did not alter the effects of RES ( $\mathrm{p}<0.01$ ) (Figs. 2, 9). 17betaE $(\mathrm{p}<0.05)$ and RES combined with TMX $(\mathrm{p}<0.01)$ significantly increased serum estradiol levels in peripubertal rats with POF (Fig. 10). There were no significant differences in serum 25 hydroxy vitamin $\mathrm{D}$ levels and bone mineral density in none of the groups of the peripubertal rats with POF.

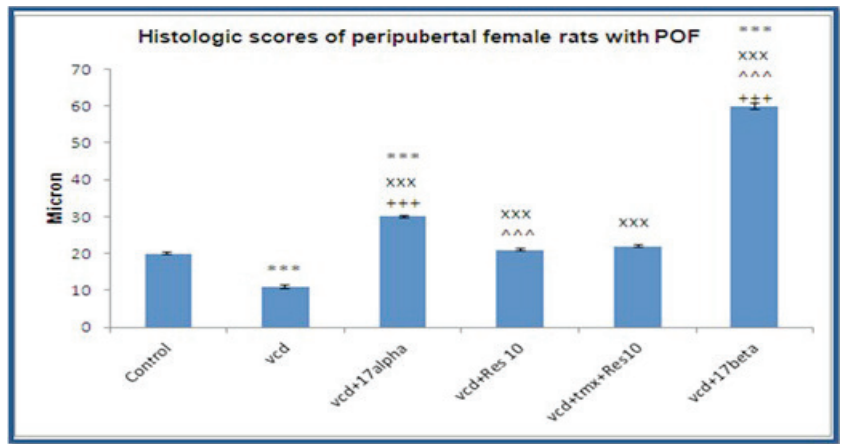

Fig. 9. Histologic Scores of peripubertal female rats with POF (Based on endometrial thickness) $(\mathrm{n}=6)$ $(*)=$ Different from control, $(* * *)=\mathrm{p}<0.001$ $(\mathrm{x})=$ Different from $\mathrm{VCD},(\mathrm{xxx})=\mathrm{p}<0.001$ $\left({ }^{\wedge}\right)=$ Different from VCD +17 alpha EE, $\left({ }^{\wedge \wedge}\right)=p<0.001$ $(+)=$ Different from $V C D+R e s 10,(+++)=p<0.001$

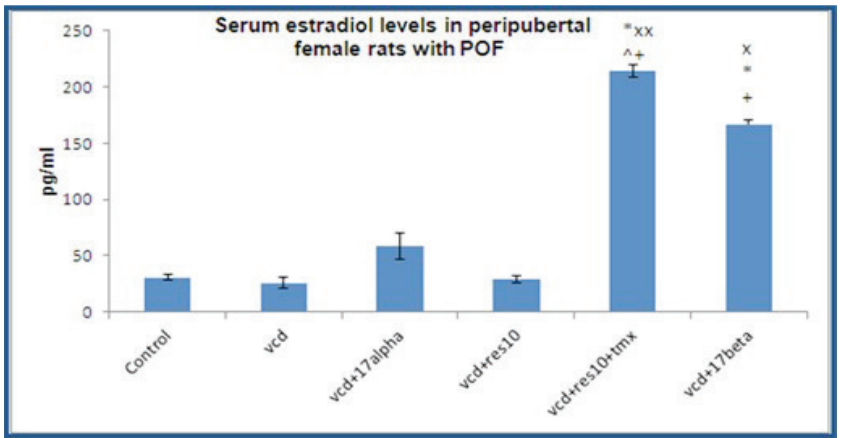

Fig. 10. Serum estradiol levels in peripubertal rats with POF $(n=6)$ $(*)=$ Different from control, $(*)=\mathrm{p}<0.05$

$(\mathrm{x})=$ Different from VCD, $(\mathrm{x})=\mathrm{p}<0.05,(\mathrm{xx})=\mathrm{p}<0.01$

$(\wedge)=$ Different from VCD +17 alpha EE, $\left({ }^{\wedge}\right)=p<0.05$

$(+)=$ Different from VCD + RES $10,(+)=p<0.05$

\section{Discussion}

In the present study, the putative estrogenic activity of RES was evaluated in immature rats and peripubertal rats with POF induced by VCD. It was found that RES increased $\mathrm{UW} / \mathrm{BW}$ as much as that resulted by the administration of 17 alphaEE. This activity was not decreased by the addition of TMX but decreased significantly by FLV Fig. 3. TMX did not antagonize the effects of RES completely in female rats with POF (Fig. 7).

Growing evidence from preclinical studies suggests that RES may have the potential to affect a variety of human diseases in appositive manner. It has been suggested that phytoestrogens may possess a weak estrogenic, selective estrogen modulating (SERM) or antiestrogenic effects [14]. In the presence of estradiol, such compounds may also have an antagonistic effect and decrease the potency of estradiol. It was suggested that the estrogenic potency 
of phytoestrogens was lower as compared to endogenous or synthetic estrogens like 17betaE and 17alphaEE [15]. There are some differences in the potency of phytoestrogens and in the molecular mechanisms of their actions. Several phytoestrogens may show different affinities to different estrogen receptor subtypes of alpha and beta $\left(\mathrm{ER}_{\alpha}\right.$ and $\left.\mathrm{ER}_{\beta}\right)$. The distribution of $\mathrm{ER}_{\alpha}$ and $\mathrm{ER}_{\beta}$ in different tissues is the molecular basis of the tissue selective action of certain drugs. TMX is known to have antagonistic activity in the mammary gland, but to exhibit agonistic activity in the endometrium [16]. SERMS are known to have antiestrogenic activity in certain tissues like mammary and uterus and estrogenic activity in some tissues like brain, bone and cardiovascular cells [17]. Phytoestrogens may also be expected to act in a tissue-specific manner. It was suggested that resveratrol have a mixed estrogen agonist/antagonist activity in some mammary cancer cell lines; but in the presence of estradiol, RES may act as an antiestrogenic compound [18]. It was also reported that RES showed antagonistic activity on $\mathrm{ER}_{\alpha}$, but not on $\mathrm{ER}_{\beta}$ [19]. It was not clear that RES is an estrogenic agonist or antagonist [20].

In the present study, we noticed that RES has a dosedependent uterotrophic activity as that of 17alphaEE (Fig. 3). It was interesting that the combination of RES2 and 17alphaEE inhibited the effects of 17alphaEE on endometrial thickness. It seems that RES has an antagonistic effect on estrogenic agonist, 17alphaEE (Fig. 5). However, this activity was not observed macroscopically in UW/ BW. Another interesting result of the present study is that there was no significant change in the levels of estradiol in all groups except the group received RES20 (Fig. 6). The high dose of RES may inhibit estradiol production. It seems that this result may be related to the antiestrogenic activity of RES. We observed a significant change in UDW/ UWW only in the group that received a combination of 17alphaEE and FLV (Fig. 4). Increased UDW/UWW may reflect the cellular responses such as increased protein, DNA and uterine peroxidase levels [21]. It seems that FLV may have some inhibitory effects on rehydration of the uterine tissues. However, there was no change in protein synthesis. Likewise, CP-336,156, a nonsteroidal estrogen agonist/ antagonist has been suggested to have a number of effects on rehydration in uterine tissue which are not elucidated yet [11].

In the second step of the present study, we aimed to evaluate the possible beneficial effects of RES on the uterus of peripubertal rats with POF by using its dose $(10 \mathrm{mg} /$ $\mathrm{kg}$ ) that had minimal uterotrophic activity. It was reported that VCD leads to selective destruction of primordial and primary follicles when administered to mice and rats by daily intraperitoneal injections [9]. RES was shown to scavenge hydroxyl radicals and superoxides and protect against lipid peroxidation in cell membranes and the ROS-related DNA damage [22]. In addition, it was reported that RES enhances intracellular antioxidant levels in cardiomyocytes and aortic muscle cells $[23,24]$. It was also indicated that RES has hepatoprotective effects and reduces oxidative stress in rats $[25,26]$. VCD is known as a lipophilic molecule and its absorption into systemic circulation results to a chemically induced inflammatory reaction [12]. It was reported that VCD is useful for perimenoposal studies and does not have long-term effects in nonovarian tissues [12]. We determined that VCD significantly inhibited UW/BW and RES and 17betaE counteracted its effects (Fig. 7). RES and 17betaE also significantly increased body weights in the rats with POF and TMX did not inhibit the effect of RES (Fig. 8). In regard to the endometrial thickness, similar results were shown in (Fig. 9). The uterine weight loss induced by VCD was attributed to the loss of trophic effects of ovarian $17 \mathrm{betaE}$ on the uteri [27]. 17betaE and the combination of RES10 and TMX significantly increased the levels of estradiol (Fig. 10). It seems that the changes in estradiol can affect appetite and body weight gain in these animals. Some changes were expected in serum levels of 25 hydroxy vitamin D and in bone mineral density in rats with POF. But no significant change was noticed in none of the groups. Taken together, these data suggest that this time period was not sufficient to induce osteoporotic changes.

In conclusion, the results of the present study suggest that dose of RES may play an important role in its estrogenic activity. It can also be thought that RES may have an estrogenic modulatory activity. Further studies are needed to clear the complete mechanism of the estrogenic modulatory activity of RES.

\section{References}

1. Jiang H, Zhang L, Kuo J, et al. Resveratrol-induced apoptotic death in human U251 glioma cells. Mol Cancer Ther 2005; 4:554-61. doi: 10.1158/1535-7163.MCT-04-0056

2. Frémont L. Biological effects of resveratrol. Life Sci 2000;66:663-73. doi:10.1016/S0024-3205(99)00410-5

3. Wolter F, Ulrich S, Stein J. Molecular mechanisms of the chemopreventive effects of resveratrol and its analogs in colorectal cancer. J Nutr 2004;134:3219-22.

4. Gehm BD, McAndrews JM, Chien P-Y, Jameson JL. Resveratrol, a polyphenolic compound found in grapes and wine, is agonist for estrogen receptor. Proc Natl Acad Sci USA 1997; 94:14138-43. doi:10.1073/pnas.94.25.14138 
5. Turner RT, Evans GL, Zhang M, Maran A, Sibonga JD. Is resveratrol an estrogen agonist in growing rats? Endocrinology 1999;140:50-4. doi: 10.1210/endo.140.1.6460

6. Lu R, Serrero G. Resveratrol, a natural product derved from grape, exhibits antiestrogenic activity and inhibits the growth of human breast cancer cells. J Cell Physiol 1999;179:297-304. doi: 10.1002/(SICI)1097-4652(199906)179:3<297::AIDJCP7>3.0.CO;2-P

7. Bhat KP, Pezzuto JM. Resveratrol exhibits cytostatic and antiestrogenic properties with human endometrial adenocarcinoma (Ishikawa) cells. Cancer Res 2001; 61:613744.

8. Eppenberger U, Woslkowski K, Kung W. Pharmacological and biological properties of droloxifene, a new antiestrogen. Am J Clin Oncol 1991; 14: 5-14.

9. Hoyer PB, Sipes IG. Development of an animal model for ovotoxicity using, 4-vinyl cyclohexene: a case study. Birth Defects Res B Dev Reprod Toxicol 2007; 80:113-25. doi: 10.1002/bdrb.20103

10. Kappeler CJ, Hoyer PB. 4-vinylcyclohexene diepokside: a model chemical for ovotoxicity. Syst Biol Reprod Med 2012; 58: 57-62. doi: 10.3109/19396368.2011.648820.

11. Ke HZ, Paralkar VM, Grasser WA, et al. Effects of CP336,156 , a new nonsteroidal estrogen agonist/antagonist, on bone, serum cholesterol, uterus, and body composition in rat models. Endocrinology 1998; 139: 2068-76. doi: 10.1210/ endo.139.4.5902

12. Muhammad FS, Goode AK, Kock ND, et al. Effects of 4-vinylcyclohexene diepoxide on peripubertal and adult Sprague-Dawley Rats: Ovarian, Clinical and Pathological Outcomes. Comparative Medicine 2009; 59:46-59.

13. Odum J, Tinwell H, Van Miller J, Joiner R, Ashby J. The uterotropic activity of nonylphenol in the rat is not mediated by aromatase enzyme induction. Toxicology Letters 2001; 118:165-69. doi: 10.1016/S0378-4274(00)00293-9

14. Oseni T, Patel R, Pyle J, Jordan VC. Selective Estrogen Receptor Modulators and Phytoestrogens. NIH Public Access 2008; 74;1656-65. doi: 10.1055/s-0028-1088304

15. Heather B, Patisaul HB, Whitten P. Dietary phytoestrogens. In: Naz RK, editor. Endocrine disruptors:effects on male and female reproductive systems. 2nd ed. Boca Raton 2004, CRC Press: $135-75$.

16. Assikis VJ, Neven P, Jordan VC, Vergote I. A realistic clinical perspective of tamoxifen and endometrial carcinogenesis.
Eur J Cancer 1996 32A:1464-76. doi: 10.1016/09598049(96)00184-0

17. Moutsatsou P. The spectrum of phytoestrogens in nature:our knowledge is expanding. Hormones 2007; 6:173-93.

18. Bhat KP, Lantvit D, Christov K, Mehta RG, Moon RC, Pezzuto $\mathrm{JM}$. Estrogenic and antiestrogenic properties of resveratrol in mammary tumor models. Cancer Res 2001;61:7456-63.

19. Bowers JL, Tyulmenkov VV, Jernigan SC, Klinge JM. Resveratrol acts as mixed agonist/antagonist for estrogen receptors alpha and beta. Endocrinology 2000;141:3657-67. doi: 10.1210/endo.141.10.7721

20. Cucciolla V, BorrielloA, Oliva A, Patrizia G, Zappia V, Della Ragione F. Resveratrol: From basic science to clinic. Cell Cycle 2007; 6: 2495-510. doi: 10.4161/cc.6.20.4815

21. Dundar Y, Ozatik Y, Ozatik O, et al. Synthesis and biological evaluation of the salicylamide and salicylic acid derivatives as anti-estrogen agents. Med Chem 2012; 8:481-90. : 10.2174/1573406411208030481

22. Leonard SS, Xia C, Jiang BH, et al. Resveratrol scavenges reactive oxygen species and effects radical-induced cellular responses. Biochem Biophys Res Commun 2003; 309:101726. doi:10.1016/j.bbrc.2003.08.105

23. Cao Z, Li Y. Potent induction of cellular antioxidants and phase 2 enzymes by resveratrol in cardiomyocytes: protection against oxidative and electrophilic injury. Eur J Pharmacol 2004;489(1-2):39-48. doi:10.1016/j.ejphar.2004.02.031

24. Li Y, Cao Z, Zhu H. Upregulation of endogeneous antioxidants and phase 2 enzymes by red wine polyphenol, resveratrol in cultured aortic smooth muscle cells leads to cytoprotection against oxidative and electrophilic stres. Pharmacol Res 2006;53:6-15. doi:10.1016/j.phrs.2005.08.002

25. Kasdallah-Grissa A, Mornagui B, Aouani E, et al. Resveratrol, a red wine polyphenol, attenuates ethanol-induced oxidative stres in rat liver. Life Sci 2007; 80:1033-39. doi:10.1016/j. lfs.2006.11.044

26. Ajmo JM, Liang $X$, Rogers CQ, Pennock B, You M. Resveratrol alleviates alcholic fatty liver in mice. Am J Physiol Gastrointes Liver Physiol 2008; 295:833-42. doi: 10.1152/ajpgi.90358.2008.

27. Lohff JC, Christian PJ, Marion SL, Arrandale A, Hoyer PB. Characterization of cyclicity and hormonal profile with impending ovarian failure in a novel chemical-induced Mouse model of perimenopause. Comparative Medicine 2006;55:523-7. 